\title{
17. Power Sharing in Fiji and New Caledonia $^{1}$
}

\section{Jon Fraenkel}

Fiji and New Caledonia adopted mandatory power-sharing institutions in an effort to mitigate conflict in the late 1990s. Both are bipolar polities, where politics has revolved around the conflicting objectives of substantial indigenous and migrant or migrant-descended groups. Both experienced severe conflict during the 1980s, culminating in a military coup in Fiji in 1987 and more than 50 people killed in New Caledonia in the 1980s. Both countries subsequently settled on compacts aimed at resolving those conflicts (the 1997 Constitution in Fiji and the 1988 Matignon and 1998 Noumea Accords in New Caledonia). Whereas Fiji witnessed a second coup only a year after the first elections under the new system and protracted controversies before the law courts over the multi-party cabinet laws, New Caledonia achieved some degree of accommodation between former antagonists, with representatives of the Kanak and settler parties sharing power in a multi-party executive. This paper examines the Fijian and New Caledonian institutions and the two countries' differing experience with multi-party cabinets, drawing also on the international literature examining power-sharing arrangements.

Internationally, mandatory power-sharing institutions do not have a particularly strong track record. The notorious collapses of power sharing in Cyprus in the early 1960s and Northern Ireland in the early 1970s suggest that such arrangements are regularly fraught with difficulties. Lebanon's 1943-75 National Pact proved more successful, but the associated institutionalisation of confessional politics left internal rigidities that were vulnerable to regional destabilisation and themselves became an issue of dissension in the run-up to the civil warfare of the post-1975 period (Seaver 2000, Kliot 1987). South Africa had some success with power-sharing devices, but these were employed as a transitional measure during the shift away from apartheid and were abandoned in 1996 (Koelble and Reynolds 1996, Lijphart, 1998). Elsewhere in Africa, particularly in post-civil warfare contexts, power-sharing arrangements have often proved fleeting and unsustainable arrangements that quickly come unstuck (Spears 2002; 2000, Akinyele 2000). Switzerland's Federal Council provides an often-cited positive model, but here power sharing is informal although reinforced by federal autonomy and direct democracy. No law prohibits majority rule in the Federal Council. Reliance on some of the northern European models also attracts criticism (Barry 1975a; 1975b) and suspicion lingers that these might not be viable in less prosperous and more deeply divided countries - such as Guyana, Iraq or Bosnia 
- where ministers from distinct communities are under greater popular pressure to play to a communal gallery.

Nevertheless, power sharing remains a continuing focus of attention, despite all evidence of difficulties. The alternatives of hegemony of one group over the other, or the mutual destruction of contending forces, are sufficiently unpalatable to encourage external mediators and in-country reformers to persevere in seeking out appropriate and workable power-sharing arrangements. Lebanon's post-civil war 1989 Ta' if Accord restored many of the 1943-75 National Pact arrangements, although with parity replacing the earlier 6:5 bias in favour of Christian representation and with a shift in power from the Maronite President to the Sunni Prime Minister (Hudson 1997, Nasrallah 1999). Northern Ireland's 1998 Good Friday Agreement also involved a renewed effort to establish Republican/Loyalist executive power sharing (O'Leary 1999, McGarry 1998). ${ }^{2}$ Methods have repeatedly been sought in post-Dayton Bosnia to bring together in government Serbs, Croats and Muslims, to combine Sunni, Shi' ite and Kurdish leaders in Iraq or the Pashtun, Tajiks, Uzbeks and others in Afghanistan. The collapse of power-sharing arrangements, where this has occurred, might owe its origins to the severity or intractability of conflict, to regional destabilisation, to the forces unleashed or strengthened by the associated empowerment of communal elites or to the absence of simultaneous civil society-based peace-building initiatives; but this might also arise due to bad timing or quick-fix approaches, the absence of involvement of key players or failures to popularly embed arrangements through referenda or elections or, last but not least, to the poor design of the institutions themselves.

One regularly preferred mix of power-sharing institutions is Arend Lijphart's (2004; 2002; 1991a; 1991b) 'consociational' model, involving usage of list proportional representation, mandatory power sharing, group autonomy and minority (or mutual) vetoes. List proportional representation has the inclusive impact of bringing the political representatives of ethnic groups into Parliament roughly in proportion to their shares in the population, while mandatory power sharing is to ensure some form of cooperation between elected leaders in government. Vetoes and autonomy, perhaps including federal arrangements, are further devices aimed at ensuring that majority groups do not simply lord it over minorities. Majoritarian institutions, such as Westminster democracy or presidentialism, are rejected as 'winner-takes-all' models that offer little to ethnically divided societies.

Lijphart prefers ethnicity-blind, or self-determination-based, power-sharing arrangements of the type adopted in South Africa to the kinds of ethnic predetermination witnessed in Lebanon's 1943-75 ratio of 6:5 between Christian and Muslim parliamentarians, or the 7:3 ratio between Greek and Turkish Cypriot ministers embodied in the 1960 Cyprus Constitution. South Africa's 1993 
Constitution provided that all parties with more than 5 per cent of seats in the National Assembly would secure cabinet portfolios and all parties with more than 20 per cent of seats would obtain a vice-presidency. ${ }^{3}$ In practice, that provision ensured that although Nelson Mandela's African National Congress easily won the 1994 elections, it did not control all the positions in the new government. F. W. de Klerk's National Party gained six and Chief Mangosuthu Buthelezi's Inkatha Freedom Party acquired three of the 27 cabinet portfolios after the 1994 elections (Reynolds 1995). ${ }^{4}$ Yet the South African power-sharing provisions did not imply a permanent allocation of positions to either party. Had the 1994 arrangements been retained, future elections might have led to the allocation of portfolios and vice-presidencies to different political parties, empowering other ethnic or interest groups.

Fiji and New Caledonia adopted Lijphart's favoured South African-style non-ethnically predetermined power-sharing arrangements in the late 1990s. In Fiji, all parties with eight or more seats in the 71-member Parliament secured legal rights to enter cabinet. In New Caledonia, all parties with six or more seats in the 52-member Congress were entitled to participate in the Executive. Fiji combined these arrangements with a majoritarian electoral system (the 'alternative vote') and a substantial number of communal constituencies (23 of the 71 seats were reserved for ethnic Fijians, 19 for Indo-Fijians and only 25 were 'open' or 'common roll' constituencies ${ }^{5}$ ). New Caledonia, despite its neglect in the international literature on power-sharing and consociational democracy, ${ }^{6}$ more faithfully reflects the Lijphartian model. It has used a list proportional representation system since the early 1950s, Kanaks have a substantial degree of autonomy in the Northern and Loyalty Islands Provinces, there is a proportionally elected multi-party cabinet, and there is an indirect minority veto. Part of the reason for the greater success of power sharing in New Caledonia than in Fiji, I argue in this paper, had to do with the design and drafting of the new multi-party cabinet laws, although there were also other reasons why cooperation was more likely to succeed under the 1988 Matignon agreement and the 1998 Noumea Accord than under Fiji's 1997 Constitution that are worth reviewing briefly.

Fiji's coups and constitutional crises (in 1977, 1987 and 2000) each came in the wake of electoral victories by predominantly Indo-Fijian-backed political parties and each centred on resurrecting 'indigenous paramountcy', whereas New Caledonia's principal conflict has been between those who back independence and those who want to remain part of the French Republic. Consequently, the French Government was intimately involved in negotiations for the Matignon and Noumea Accords, and was influenced by UN pressures towards 'decolonisation' (de Fontenay 2001). In Fiji, retention of the status quo, coupled perhaps only with a few cosmetic changes, seemed a more plausible strategy 
during the mid-1990s deliberations than it did in New Caledonia, particularly given the likely electoral repercussions of the growing numerical advantage of ethnic Fijians. The mid-1990s constitutional review at first seemed likely to make few alterations to the racially discriminatory 1990 Constitution. Fijian Prime Minister Sitiveni Rabuka's efforts to win support for the 1997 Constitution within his Soqosoqo ni Vakavulewa ni Taukei (SVT) Party were couched in terms of the likelihood of Fijian retention of the premiership coupled with concessions of only the deputy premiership and cabinet representation to Indo-Fijians. In contrast, reversion to the style of politics of the 1950s and 1960s (i.e., liberal multi-ethnic Kanak-backed territorial government with little real autonomy from France) never seemed a realistic option in New Caledonia after the conflict of the 1980s. Once the peace process seemed to be paying political dividends, even changes in government in metropolitan France did not derail continuing efforts to strengthen cooperation around the implementation of the Noumea Accord.

Potential benefits associated with the 'buy in' to the accords differed in New Caledonia and Fiji. Under the Matignon and Noumea Accords, heavy metropolitan subsidies and rebalancing (rééquilibrage) in favour of Kanak communities in the north and in the Loyalty Islands offered a pay-off associated with the peace process, and fostered patronage systems that enticed veteran pro-independence leaders to break away and form alliances with loyalist leaders and created tensions within the independence movement itself (Chappell 1999a, Connell 2003). By contrast, the 1997 Fijian Constitution offered few tangible benefits, aside from re-entry into the Commonwealth. The accommodation between Rabuka and Indo-Fijian Opposition Leader, Jai Ram Reddy, provided little in the way of immediate advantages for the Indo-Fijians, particularly given the absence of any associated deal on the issue of the expiry of sugarcane farming leases under the 1976 Agricultural Landlord and Tenants Act. Indian overseas migration continued through the 1990s, and intensified difficulties faced Reddy's National Federation Party (NFP), which secured only 32 per cent of the Indian vote at the 1999 polls and consequently obtained not a single seat in Parliament. Mahendra Chaudhry's Fiji Labour Party (FLP) campaigned at the 1999 polls on the slogan 'the constitution won't put food in your mouths', and, once in office, offered a range of measures aimed at assisting poorer citizens of both communities, including the abolition of VAT on basic food items. With time, the FLP's Fijian allies in the People's Coalition might have cemented indigenous support behind the Government, but after the first year in office the signs were not promising. All three Fijian parties had splintered; while their leaders remained in cabinet, many rank-and-file members joined opposition efforts to destabilise the Government. None of the Fijian cabinet ministers in the Chaudhry Government proved able to secure election, drawing on indigenous Fijian votes, at the 2001 election. ${ }^{7}$

Finally, New Caledonia had a history of mandatory power sharing, from 1976 to 1979 and briefly again under the 1988 Pons Statute, as well as informally (i.e., 
through non-mandatory methods), in successive pro-autonomy administrations run by the Union Calédonienne (UC), which was able to secure Melanesian and liberal European support for most of the postwar period until the 1970s. By contrast in Fiji, Ratu Sir Kamisese Mara's Alliance Party was never able to surpass the 25 per cent share of the Indian vote it received in 1972. From the 1987 coup onwards, mainly Indian-backed parties could count on no more than 2 or 3 per cent of the nationwide Fijian vote and mainly Fijian-identified parties gained less than 1 per cent of the Indian vote. Some degree of power sharing had been achieved in the 'membership system' of 1964-67, in which representatives of the three major communities, Ratu Mara, A. D. Patel and Sir John Falvey, had shared portfolios with colonial officials (Norton 2004: 165; 2002: 147, Lal 1992: 191). But, crucially, this was before independence in 1970. Prime Minister Ratu Mara proposed a Government of National Unity in 1980, although controversially so since this was on the basis of the weakened representation secured by the NFP at the September 1977 polls. Equal representation between antagonistic parties had been mooted after the 1987 coup in the Deuba Accord, before this was derailed by a further coup in September of that year. Power sharing was a realistic, and much debated, possibility in mid-1990s Fiji, but it would have been necessary to overcome a long history of much more rigid ethnic compartmentalisation than prevailed in postwar New Caledonia.

\section{The making and unmaking of Fiji's multi-party cabinet laws}

Fiji's 1997 Constitution was intended to put an end to a decade of inter-ethnic discord after the military coup in 1987, which dislodged a largely Indo-Fijian-backed government. The post-coup administration put in place an interim constitution in 1990, which reserved the presidency and the premiership for indigenous Fijians and reverted to an entirely communally-based electoral system with seats unevenly distributed in favour of ethnic Fijians (who obtained 37 seats as against 27 for Indo-Fijians in a 70-member Parliament, despite the two populations being roughly equal in number at that time). In the mid-1990s, Rabuka's Government appointed a Constitutional Review Commission (CRC) to advise on amendments to Fiji's fundamental laws. The CRC engaged in extensive consultation, in Fiji and abroad, including a visit to South Africa to assess the merits of the power-sharing arrangements adopted in that country. That visit occurred in 1996, just as South Africa was about to abandon its transitional multi-party cabinet laws. The CRC concluded that mandatory power sharing was fraught with difficulties. ${ }^{8}$ It advised instead retention of the Westminster model, with the institutional encouragement of multi-ethnic government to be provided instead by the adoption of the alternative vote system. Instead of the post-election coalitions facilitated by mandatory power-sharing laws, the alternative vote, it was hoped, would encourage robust pre-election coalitions arising from deals over party preferences. ${ }^{9}$ 
The Joint Parliamentary Select Committee that gathered to deliberate on the CRC report departed from some of the CRC's recommendations. In particular, it announced an intention to 'go further' in the direction of encouraging multi-ethnic government by embracing a power-sharing deal (Parliament of Fiji 1997: 17). At first, all parties with more than 4 per cent of the seats in the House were to be invited by the Prime Minister to join cabinet. That threshold was later raised by Parliament to 10 per cent, and included in Section 99 of the 1997 Constitution. Subsection 99(5) of the 1997 Constitution specified that

In establishing the Cabinet, the Prime Minister must invite all parties whose membership in the House of Representatives comprises at least $10 \%$ of the total membership of the House to be represented in proportion to their numbers in the House.

The section covering appointments to the 32-member Senate - which was to include 14 members appointed by the Great Council of Chiefs, nine appointed by the Prime Minister, eight by the Leader of the Opposition and one by the Council of Rotuma - also entailed a multi-party distribution of members nominated by the Leader of the Opposition.

[T] he Leader of the Opposition must ensure that the 8 persons proposed for appointment comprise such number of nominees of those parties as is proportionate to the size of the membership of those parties in the House of Representatives (Constitution of Fiji 1997, 64(2)).

As the courts later pointed out, insufficient attention was directed towards reconciling these new government formation rules with the underlying bedrock of Westminster democracy. The result was a hybrid Westminster system with superimposed multi-party cabinet provisions governing formation of cabinet and the Senate. Prime Ministers still needed to 'command a majority' on the floor of the House, but also to appoint ministers in accordance with Section 99. The formulas required for determining cabinet allocations and the distribution of nominees by the Leader of the Opposition in the Senate were not entirely clear, there was no ceiling on cabinet membership, there were no controls (aside from 'consultation' initiated by the Prime Minister) granted to participating parties as to which MPs might be selected and there were no rules governing the conduct of cabinets (or preventing government by single-party caucus reducing cabinet to a mere talking shop). The poorly drafted section covering Senate appointments specified a proportional distribution only of opposition nominees, but not those nominated by the Prime Minister (and potentially entailed a double dip for the Prime Minister's party, which might, in theory, have been entitled to secure some of the Leader of the Opposition's nominees as well as all of those of the Prime Minister). These arrangements proved a source of continuing litigation after the 1999 and 2001 elections. 


\section{Outcomes of the 1999 election}

After the 1999 elections, the FLP emerged with an absolute majority (37 of 71 seats). It had a formal coalition with two smaller, Fijian-backed parties (the Fijian Association Party [FAP], with 11 seats, and the Party of National Unity [PANU], with four seats - see Table 1). It also had entered some informal arrangements with the Fijian Veitokani ni Lewenivanua ni Vakarisito (VLV, with three seats) about the exchange of preference votes (cf. Fraenkel 2001). After the election, FLP leader, Chaudhry, unexpectedly and controversially became Prime Minister, the first time an Indo-Fijian leader had ever assumed that position. Given the coup that had occurred in the aftermath of the FLP's previous victory in 1987, FLP coalition-building was inevitably sensitive to the broader security situation, rather than being narrowly constrained by the multi-party cabinet laws. Although the VLV held only three seats, its MPs included family members of the ethnic Fijian President, Ratu Mara, whose influence was critical for the survival of the new government. Two of these VLV MPs, including Mara's daughter, were granted cabinet positions, along with three FAP MPs and two PANU MPs. According to the Constitution, neither the VLV nor PANU was entitled to ministerial portfolios (and therefore these allocations were legally part of the Prime Minister's party entitlements). The political imperative of creating a broadly based coalition government, with a good number of ethnic Fijian ministers, took precedence over the formal power-sharing requirements.

Table 1: Composition of the Fijian Parliament, eligibility of parties under the 10 per cent rule and the make-up of cabinet as of June 11, 1999

\begin{tabular}{|c|c|c|c|c|}
\hline & \multicolumn{2}{|c|}{ Parliamentary seats } & \multicolumn{2}{|c|}{ Cabinet positions } \\
\hline & No. & $\%$ & No. & $\%$ \\
\hline \multicolumn{5}{|c|}{ Qualifying parties: } \\
\hline FLP & 37 & 52.1 & 11 & 61.1 \\
\hline FAP & 11 & 15.5 & 3 & 16.7 \\
\hline SVT & 8 & 11.3 & 0 & 0 \\
\hline \multicolumn{5}{|c|}{ Non-qualifying parties: } \\
\hline PANU & 4 & 5.6 & 2 & 11.1 \\
\hline VLV & 3 & 4.2 & 2 & 11.1 \\
\hline UGP & 2 & 2.8 & 0 & 0 \\
\hline NVTLP & 1 & 1.4 & 0 & 0 \\
\hline Independents & 5 & 7 & 0 & 0 \\
\hline Total & 71 & 100 & 18 & 100 \\
\hline
\end{tabular}

Source: Parliamentary seats from Fiji Elections Office, 'Elections '99; results by the Count', Suva, 1999; cabinet portfolios from the 'Statement of Agreed Facts and Issues in Supreme Court of Fiji, Miscellaneous Case No. 1 of 1999 between the President of the Republic of the Fiji Islands and 1. Inoke Kubuabola (Leader of the Opposition), 2. Mahendra Pal Chaudhry, Prime Minister, Government of the Fiji Islands and Leader of the Fiji Labour Party and 3. Adi Kuini Speed, Leader of the Fijian Association Party (cited as The President of the Republic of the Fiji islands v. Kubuabola \& others, Misc. 1/1999, September 3, 1999).

Notes: Seats include adjustment for June 11, 1999, revocation of election of NVTLP candidate for Tailevu North/Ovalau in favour of the FAP. FLP = Fiji Labour Party; FAP = Fijian Association Party; SVT = Soqosoqo 
ni Vakavulewa ni Taukei; PANU = Party of National Unity; VLV = Veitokani ni Lewenivanua Vakarisito; $U G P=$ United Generals Party; NVTLP = Nationalist Vanua Lavo Tako Party.

Nevertheless, the new government remained precarious. The FLP had been party to the negotiations over the 1997 Constitution, but the key players had been the SVT and NFP, both of which had experienced heavy defeat at the polls. The SVT remained the largest indigenous party in terms of its share of the Fijian vote (38 per cent), but usage of the new alternative vote system had left it with only eight seats (as compared with the 18 it might have received under the former first-past-the-post system). Nevertheless, with eight seats, the SVT just reached the 10 per cent threshold for inclusion in cabinet. As constitutionally required, Chaudhry issued a lawful invitation to the SVT to join the cabinet. The SVT accepted, but insisted that party leader, Sitiveni Rabuka, become Deputy Prime Minister, that the SVT secure a total of four cabinet positions and three of the Prime Minister's Senate nominees, and that all SVT diplomatic appointees, as well and those appointed to statutory and state-owned boards, complete their terms of appointment. ${ }^{10}$ The Prime Minister responded by rejecting these conditions. In the newspapers, the SVT announced a decision to lead the opposition and Rabuka resigned the leadership to become instead the Chair of the Great Council of Chiefs. Accordingly, a cabinet was formed that excluded the SVT, as shown in Table 1. New SVT leader, Ratu Inoke Kubuabola, was sworn in by the President as Leader of the Opposition. Only in July, with Supreme Court hearings looming over the allocation of positions in the Senate, ${ }^{11}$ did the SVT lodge a protest against 'the decision of the Prime Minister to exclude the SVT from Cabinet'. ${ }^{12}$

The conditions in the SVT letter were deliberately severe. ${ }^{13}$ Based on the 18-member cabinet eventually put together by Prime Minister Chaudhry, the SVT would have been entitled to no more than two or three cabinet positions. ${ }^{14}$ According to Fiji's Supreme Court, '[T]hese were clearly conditions which the Prime Minister, acting reasonably, was not bound to accept. The Constitution does not provide for an acceptance qualified in this way. In the circumstances, what purported to be a conditional acceptance amounted to a declining of the invitation.' 15

For this reason, the court upheld the constitutionality of the People's Coalition cabinet. Whatever the legal position, from the standpoint of rendering effective the new multi-party cabinet provisions or embedding support for the new Constitution among Fijian leaders, that decision, as well as the absence of negotiations on the issue of including SVT leaders in the new cabinet, was problematic. The SVT leaders were left in opposition, and quickly became involved in efforts to galvanise indigenous Fijian disquiet and unite Fijian parties, including backbenchers from among the FLP's coalition allies, against the Government. The consequent political climate, although it varied in intensity 
during the FLP's year in office, had much to do with the putsch that occurred on May 19, 2000 (cf. Fraenkel 2000).

\section{Outcomes of the 2001 polls}

Although that putsch was ultimately defeated, the FLP-led 1999-2000 government was never restored. Instead, an all-Fijian interim government assumed office. In the wake of a landmark Court of Appeal decision in March 2001 restoring the Constitution (the Chandrika Prasad case), fresh elections were held in August 2001. This time, a newly formed Fijian party, the Soqosoqo ni Duavata ni Lewenivanua (SDL), gained the largest number of seats, and party leader, Qarase, became Prime Minister. This was a truer test for the multi-party cabinet laws, since - as we saw - the post-1999 cabinet had been influenced more by security concerns than legal constraints. This was also closer to the type of situation envisaged by the drafters of the Constitution. With a growing majority in the population, the indigenous Fijians had been expected in the mid-1990s to be likely to secure the premiership, and the power-sharing provisions had been aimed principally at ensuring that they would do so in cooperation with Indo-Fijian political leaders. But the coup had polarised Fiji along ethnic lines, and annihilated much of the goodwill that had accompanied the negotiations on the 1997 Constitution. The 2001 elections were fought as a 'winner-takes-all' affair, with the SDL's principal campaign strategy being an appeal to indigenous Fijians to keep the FLP from returning to office. In the wake of the elections, multi-party cabinet provisions were to receive their sternest test.

That the SDL did not have an absolute majority after the 2001 polls also influenced the multi-party cabinet negotiations. The SDL had 32 seats, while the FLP had 27 seats (see Table 2). ${ }^{16}$ No other party crossed the 10 per cent threshold. To form a durable majority government, Qarase obtained the support of the Conservative Alliance-Matanitu Vanua (CAMV, six seats), and formed a government with the backing of 41 of the 71 members. As constitutionally required, the new Prime Minister wrote to Chaudhry on the day of his appointment extending an invitation to participate in cabinet, but also pointing out that the two parties had 'diametrically opposed' policies and that there existed insufficient basis for a workable partnership. His letter stated that in the contemporary political context, Section 99(5) of the Constitution was 'unrealistic and unworkable', and made clear that government would be based on SDL policy. ${ }^{17}$

Chaudhry's response, also on September 10, accepted the invitation to join cabinet, although the FLP leader demanded representation in cabinet in accordance with the Korolevu Declaration, a pact that had been signed between political parties shortly before the 1999 polls. This had suggested a slightly modified interpretation of the constitutional power-sharing provisions such that the proportional entitlement of parties that crossed the 10 per cent threshold 
would be calculated not on the basis of their membership of the entire House (71 seats), but rather specified that 'membership of the cabinet should be in proportion to the number of seats held in parliament by those parties participating in the cabinet ${ }^{\prime} 18$ (in this case, $32 \mathrm{SDL}+27 \mathrm{FLP}=49$ ). The Korolevu Declaration had also specified that 'cabinet decision making in Government should be on a consensus seeking basis especially with regard to key issues and policies'. ${ }^{19}$ No such requirement had been included in the 1997 Constitution.

Hoping to follow the familiar 1999 sequence of events, in a further letter, Prime Minister Qarase stated that he was no longer obliged to include Labour in cabinet since Chaudhry had not accepted the 'basic condition' that the cabinet be based on SDL policies. Qarase also rejected the Korolevu Declaration, describing this as an agreement into which the SDL had not entered as a signatory. He highlighted public statements in the press by Chaudhry emphasising differences between SDL and FLP policy and pointed out that a workable coalition had already been forged with independents and smaller parties which had 'accepted the SDL manifesto as the central policy guidance of Cabinet':

As your party has not accepted the same condition, I can only assume that you are unwilling to make a commitment at the outset, which would best promote the object of a stable and workable government which, in turn, would best assure the effective promotion of national unity. In all the above circumstances, I regret to say that the conditions of your acceptance of my invitation are unacceptable, as they will not contribute to a stable and workable Cabinet, so essential to the promotion of national unity in Fiji. ${ }^{20}$

On September 18, 2001, the Prime Minister wrote to the President advising the appointment of SDL and CAMV members and independents. Qarase gave two ministerial portfolios to the CAMV, one to a floor-crossing member of the NLUP and another to an independent (see Table 2). As is invariably the case with modern Fijian-led cabinets, portfolios were distributed carefully not solely along party lines, but to ensure some balance between indigenous political leaders from the major Fijian provinces and confederacies. ${ }^{21}$ 
Table 2: Composition of Fijian Parliament, eligibility of parties under the 10 per cent rule and make-up of cabinet as of September 26, 2001

\begin{tabular}{|c|c|c|c|c|}
\hline & \multicolumn{2}{|c|}{ Membership of House } & \multicolumn{2}{|c|}{ Cabinet positions } \\
\hline & No. & $\%$ & No. & $\%$ \\
\hline \multicolumn{5}{|c|}{ Qualifying parties: } \\
\hline SDL & 32 & 45.1 & 16 & 80 \\
\hline FLP & 27 & 38 & 0 & 0 \\
\hline \multicolumn{5}{|c|}{ Non-qualifying parties: } \\
\hline CAMV & 6 & 8.5 & 2 & 10 \\
\hline NLUP & 2 & 2.8 & 1 & 5 \\
\hline UGP & 1 & 1.5 & 0 & 0 \\
\hline NFP & 1 & 1.5 & 0 & 0 \\
\hline Independents & 2 & 2.8 & 1 & 5 \\
\hline Total & 71 & 100 & 20 & 100 \\
\hline
\end{tabular}

Source: Opinion of the Supreme Court in the Matter of Section 123 of the Constitution Amendment Act 1997 and in the Matter of a Reference by the President for an Opinion in Questions as to the effect of Section 99 of the Constitution, Miscellaneous Case No. 1 of 2003, Judgment, July 9, 2004, pp. 4-5.

Notes: $S D L=$ Soqosoqo ni Duavata ni Lewenivanua; CAMV = Conservative Alliance-Matanitu Vanua; for other designations, see Table 1.

In the wake of the formation of the new government, Fiji's Chief Justice lamented that the letter and spirit of the Constitution under the section pertaining to the formation of a Cabinet based on the constitutional concept of a multiparty government would appear to have been overlooked' (PINA News Online 14 September, 2001). Qarase and Chaudhry wrote to the President, Ratu Josefa Iloilo, urging, respectively, acceptance and rejection of the constitutionality of the newly sworn-in cabinet (Fiji Daily Post 21 September 2001). Unlike in the wake of the 1999 polls, the President did not refer the matter directly to the Supreme Court. Instead, the controversy over the constitutionality of the post-2001 poll cabinet, which was to dominate the political agenda for the next three years, was first brought by the FLP before the High Court in Lautoka, in western Viti Levu, which then requested advice from the higher courts. There followed a succession of judgments, in the Court of Appeal and then twice in the Supreme Court, each pitting government lawyers against those representing the FLP.

\section{Court of Appeal judgment}

In the first of these judgments, the Court of Appeal found 'no basis at all for allowing the Prime Minister to impose any conditions on the invitations he must make', refusing to be swayed by any 'potential difficulties, real or imaginary, of a Cabinet constituted in accordance with that provision':

The obligation placed on the Prime Minister is clear and precise. There is no ambiguity. There is no necessity for reading in any words. Any practical difficulties that may arise in the working of a multiparty cabinet 
cannot affect the clear meaning of the words. The 1999 Supreme Court Opinion makes it clear that a prime object of the Constitution is to promote the sharing of power. A construction that would allow the Prime Minister to impose a condition requiring a qualified party to agree to conform to the policies of the Prime Minister is contrary to the Opinion of the Supreme Court. We therefore hold that [the Constitution] obliges a Prime Minister to invite, in unconditional terms, parties which have $10 \%$ or more of the membership of the House to be represented in the Cabinet in accordance with that provision. This means the invitation to be represented in the Cabinet may have to be issued across political lines. 22

Nevertheless, the court found that Qarase's 'invitation was unconditional' and therefore in accordance with the Constitution. It was in the wake of Chaudhry's acceptance letter that 'the Prime Minister breached a constitutional duty' and, the court found, he remained in breach of those duties. On 24 April 2002, the High Court gave effect to the Court of Appeal's ruling, and required the Prime Minister to advise the President to appoint to cabinet 'such number of parliamentary members of the Fiji Labour Party as is in proportion to their numbers in the House of Representatives'. 23 The Government appealed, resulting in a fresh case heard before Fiji's Supreme Court.

\section{Supreme Court judgment}

The Supreme Court upheld the decision of the Court of Appeal, agreeing that the requirement that the Prime Minister issue invitations to entitled parties was unambiguous, that Qarase's letter of invitation on September 10, 2001, had been unconditional and that the SDL leader had breached the Constitution in not subsequently appointing FLP ministers. It found that 'an invitation issued with a prognosis that the functioning of the Cabinet will be difficult or close to unworkable does not thereby cease to be an invitation'. ${ }^{24}$ Nevertheless, the 2003 Supreme Court judgment sought to meet the Prime Minister's concerns regarding the potential unworkability of a multi-party cabinet. Although power sharing implied that rival parties might take into cabinet deliberations their 'own policies and agendas',

[i]f they do so however, they do so subject to the requirements of collective responsibility and confidentiality which are recognised in the Constitution as aids to effective government. This may mean a more difficult Cabinet to manage than a Cabinet whose members belong to the same party or a coalition that has worked out some consensus before its formation. But this is the kind of Cabinet that is envisaged by the Constitution and it cannot be rejected as unworkable in principle because of that difficulty. 25 
And there the court's involvement in the deliberations surrounding cabinet formation might have ended were it not for the fact that the 2003 Supreme Court judgment sowed the seeds of further litigation in the course of one effort to allay fears, expressed by the Government's lawyers, that the Prime Minister's party might have only a minority within cabinet:

[W] hen, as has occurred, there are only two parties which have more than $10 \%$ of the membership of the House, the Prime Minister can ensure that the majority party has a majority in the Cabinet ... It may also be noted that as long as the Prime Minister's party has a majority of the total of parliamentary seats held by that party and all other eligible parties it will have an entitlement to a majority of positions in Cabinet. For assuming each eligible party accepts the invitation for representation in the Cabinet its entitlement to representation will be measured by the proportion of the number of parliamentary seats it holds to the total number of parliamentary seats held by the Government or Coalition party and all eligible parties. On that basis, in the present case, the Prime Minister's party has an entitlement to a majority position in Cabinet. ${ }^{26}$

The penultimate sentence specified a proportional distribution of cabinet entitlements relative to the total of eligible parties (as in the New Caledonian, 1998 Northern Irish and 1994-96 South African rules ${ }^{27}$ ), rather than relative to the membership of the House as a whole. According to the first interpretation, the FLP might have gained 47 per cent of cabinet positions (28/60). According to the second, it might secure 39 per cent (28/71). ${ }^{28}$ The FLP's submissions had urged a court verdict in line with the January 1999 Korolevu Declaration. But the 2001 Court of Appeal judgment and the 2003 Supreme Court judgment rejected this FLP argument on the grounds that the Korolevu declaration was a document prepared by the leaders of certain political parties in January 1999 to which the SDL never assented'. ${ }^{29}$ Despite this, neither the Court of Appeal in 2002 nor the 2003 Supreme Court judgment specified precisely how cabinet entitlements should be calculated or what number of cabinet positions the FLP could expect to receive.

With the Supreme Court case concluded, Prime Minister Qarase announced his intention to form a 36-member cabinet, with the FLP to be granted 14 positions (38 per cent) and 'the balance of 22 is the Prime Minister's share'. ${ }^{30}$ Qarase rejected the option of calling fresh elections, anticipating that these would produce a result similar to those in 2001, therefore entailing a repeat of the multi-party cabinet controversies. To retain his coalition government (and therefore his majority on the floor of the House), the Prime Minister construed it necessary to retain the services of his existing 22 ministers. ${ }^{31}$ That cabinet, as we saw earlier, had been carefully assembled to ensure a balance between the provinces, as well as between parliamentary coalition partners. Any ministerial 
reshuffles to accommodate the court's ruling would have been likely to destroy that balance, and the wounded pride of those who lost their portfolios would have been likely to have political repercussions. As a result, Qarase might lose the confidence of the House. The FLP would have been unlikely to step in to back the Government in a confidence vote. Only by expanding the cabinet to 36 members could the governing coalition be retained intact while ensuring that the FLP was constitutionally included. The FLP was to be offered a host of token ministries, with minimal responsibilities (Daily Post 7 August 2003).

In response, Chaudhry criticised the proposed 36-member cabinet as a costly and oversized burden on the taxpayer. The FLP leader also disputed the Prime Minister's authority to choose which FLP members might take up portfolios and demanded 17 (47 per cent) rather than 14 (39 per cent) positions in a 36-member cabinet (Daily Post 27 July, 2003; 7 August 2003). The FLP refused, as requested by Qarase, to submit names for consideration until the issue of cabinet entitlements had been settled legally, and soon launched yet another High Court case on this matter. Chaudhry wrote to Qarase, making clear reference to the 2003 Supreme Court's implied inclusion of the Prime Minister's party in any calculation of entitlements in cabinet:

I have carefully considered your formula restricting Labour to 38 per cent for Cabinet seats. May I point out that applying the same formula to your own party would restrict it to a maximum of 16 ministers in a Cabinet of 36, based on the fact that the Soqosoqo Duavata ni Lewenivanua Party holds 45 per cent of the 71 seats in the House. You will agree that 45 per cent of 36 comes to 16 but you have 19 SDL ministers in your present Cabinet of 22 and you intend to retain the same number in the extended Cabinet of 36, that is three more than your entitlement using your own formula (Daily Post 11 August 2003).

By agreement between the two parties and with the assent of the President, this issue of numerical cabinet entitlements was referred back to the Supreme Court for further deliberation.

By 2003, Talanoa talks aimed at bringing together the two main party leaders had failed, and the FLP was publicly justifying its decision to pursue the issue of multi-party cabinet entitlements as intended primarily to clarify for the future ambiguous sections in the law, rather than as likely to lead to an accommodation in government. Senior FLP leaders acknowledged that a genuine partnership in cabinet between the SDL and FLP was unlikely, given the extent of bitterness and rancour between senior leaders. No compromises were offered publicly by either party leader, for example, to exchange raw numerical cabinet entitlements for favoured portfolios or concessions on policy issues which were significant to one or other of the two communities. Chaudhry explicitly emphasised that the proper application of the court ruling required the Prime Minister to 
dismantle the coalition that gave him a majority in the House: '[Y]our argument to retain your ineligible coalition partners and an independent minister in addition to a full complement of your own party ministers in order to retain and maintain your position as PM and the confidence of the House runs counter to the court's judgement' (Fiji Times 2 August 2003).

For the FLP, the multi-party cabinet court controversies were to become, ever more explicitly, a method of breaking up the governing coalition and casting perpetually into doubt the legitimacy of the Government due to its breach of the letter, as well as the spirit, of the 1997 Constitution. International opinion was also rallied in defence of this cause, although politicians schooled in the majoritarian traditions of Australia and New Zealand were not greatly sympathetic to Chaudhry's pleas. For the SDL-led Government, repeated court cases kept ethnic polarisation at the forefront of Fiji's politics and emphasised the need for 'Fijian unity' in the face of a threatened return of Chaudhry and his colleagues into government. Inter-ethnic polarisation, and the need to placate Fijian discontent had, after all, been the principal justification for the emergence of the SDL in the wake of the 2000 coup. ${ }^{32}$ To justify holding to its uncompromising stance on the multi-party cabinet issue, senior SDL leaders pointed to the precedent of Rabuka's SVT which, it was thought, had sown the seeds of its own demise by opting for a more conciliatory stance towards Indo-Fijians. ${ }^{33}$ Instead of fostering compromise, the power-sharing provisions in the Constitution had become the principal focus of inter-ethnic antagonism, serving to sustain and entrench the polarisation of 1999-2000. Compromise seemed unnecessary over an issue that was, repeatedly, being settled by recourse to the law courts.

\section{The 2004 Supreme Court judgment}

In its 2004 judgment, the Supreme Court acknowledged that its 2003 interpretation of the proportional entitlements of parties in cabinet had not been 'the product of detailed submissions and close scrutiny of earlier precedent involved in the present reference'. 34 Now required to rule expressly on numerical cabinet entitlements, the court found that the Prime Minister's own party, as well as other qualifying parties, was constrained by the provisions regarding cabinet entitlements. It rejected the interpretation, based on a literal reading of s. 99(5) in isolation, which implied that the Prime Minister was obliged to issue an invitation only to other parties which crossed the 10 per cent seat threshold and which identified proportional entitlements based on the membership of the House as a whole. It did so because later subsections implied that the party of the Prime Minister was also bound by the proportionality provisions, rather than being the recipient of all residual places after allocations to those parties entitled to mandatory representation. ${ }^{35}$ It made reference also to the section of the Constitution governing Senate appointments where 
proportionality is established by reference to the total only of the qualifying parties, not the total membership of the House. ${ }^{36}$

Yet, as in the case of the 2003 judgment, the majority opinion of the Supreme Court recognised conflicting elements in the 1997 Constitution, and, controversially, sought an interpretation enabling consistency with its majoritarian aspect. On this issue, the court was divided. The majority opinion noted that agreeing to the FLP submission 'entails the possibility of a Cabinet dominated numerically by parties hostile to the Government, with the consequence that the Cabinet (or government) would not have the confidence of the House'. 37 Whereas the majority's interpretation of proportional party entitlements implied an inflexible constraint on the Prime Minister's freedom of action, room for manoeuvre was restored by a new interpretation of the scope for independent or non-party affiliated Senate members into cabinet:

Cabinet [need not] be composed only of members of qualifying parties. [This allows] for the appointment of Independents or Senate members, provided they do not belong to any of the parties represented in the House of Representatives. But whether the Cabinet is composed only of members of qualifying parties or includes non-party appointments, the relationship between the number of seats held by the Government and qualifying non-government parties must remain the same. ${ }^{38}$

In other words, the SDL Government might appoint to cabinet as many non-party MPs or Senators as it deemed fit, needing to retain only the $32 / 28$ or 1.14 ratio of SDL to FLP cabinet ministers. The reasoning here was aimed explicitly at strengthening the position of the governing party:

Given that some constituencies may be represented by Independents and that persons of standing and experience may be appointed to the Senate who are not necessarily members of a political party, there is no apparent constitutional purpose to be served by precluding the Prime Minister from appointing a person or persons in those categories into the Cabinet in appropriate circumstances. Such appointments could involve co-operative arrangements with the governing party. 39

The minority opinion, lodged by Justice Thomas Gault, strongly criticised this aspect of the majority judgment as unnecessary to resolve the matters under dispute and inconsistent with Section 99 of the Constitution. ${ }^{40}$ Justice Gault suggested that the majority's interpretation implied unwarranted unfairness to smaller political parties, and an unjustified bias in favour of independents and Senate members. For Gault, independents should have been treated in the same way as parties that failed to secure the 10 per cent threshold (i.e., that they might obtain portfolios only as part of the Prime Minister's or other qualifying parties' entitlements). 
After the 2004 judgment, Qarase offered the FLP 14 seats in a 30-member cabinet (preserving the court's required 1.14 ratio), specifying a list of minor portfolios and the names of FLP members for inclusion, but making clear his government's intention to exercise the right to appoint additional independents and non-party Senators (Fiji Sun 23 July 2004). Even before the Supreme Court's decision, the FLP had issued a further writ challenging the Government's right to choose which FLP members might be included in cabinet (Fiji Sun 18 March 2004). But the protracted 2001-04 sequence of court controversies was over. Public opinion was tiring of the multi-party cabinet controversies, and newspaper editorials repeatedly berated both senior party leaders for their intransigence. The FLP recognised its efforts to use the courts to undermine the governing coalition were likely to prove fruitless. A new election was looming in 2006, and the 2004 Supreme Court decision had given the Prime Minister considerable scope to retain his majority in cabinet. In November 2004, Chaudhry formally rejected the Prime Minister's invitation to join the cabinet and became Leader of the Opposition.

The 2004 Supreme Court decision ended a period of protracted controversy about the multi-party cabinet, which had endured for more than half the government's five-year term in office. In compliance with the 2004 Supreme Court judgment, a Prime Minister could henceforth pack the cabinet with sympathetic independents and senators, and so diminish the portfolios held by rival parties. The strategic repercussions of operating under this new ruling are peculiar. Since encouraging more allied independents to stand for Parliament would potentially diminish a Prime Minister's own party entitlements under the 10 per cent rule, the incentive exists to appoint a good number of non-elected Senators to cabinet (as we saw above, the Prime Minister appoints nine of the 32 Senators). The only constraint is that the Prime Minister's own party has to retain its House of Representatives proportions to other entitled parties. Fiji's multi-party cabinet laws had deliberately discriminated against smaller parties (those obtaining less than 10 per cent of the membership of the House). Now its application based on legal precedent potentially discriminated against larger parties as well, but in favour of the Prime Minister's own nominees to the Senate. Whichever way, the 2004 judgment undermined the objectives of power sharing in Fiji, even if this was a response to ambiguities left in the 1997 Constitution and poor legal drafting.

\section{Unravelling majoritarian rule in New Caledonia}

As in Fiji, New Caledonia's power-sharing rules were part of a broader compact between political leaders from the two major communities, entailing a host of concessions and compromises. The 1998 Noumea Accord put back the scheduled vote on independence for 15-20 years, established a program for a phased devolution of powers to the territorial Congress and a Senate for Kanak chiefs, 
as well as providing for a government 'elected by the Congress on a proportional basis'. 41 The Organic Law of March 19, 1999, and the 1999 Standing Orders (or 'Interior Rules') of the New Caledonia Congress put this provision into practice by specifying that all 'elected groups' with more than six seats in Congress were entitled to positions in cabinet. ${ }^{42}$ Under the new arrangements, Congress established the size of the Executive, but was constrained to choose between five and 11 ministers. Qualifying groups with more than six seats, which could consist of combinations of allied parties, put up lists of candidates for inclusion in cabinet. Ministers were then selected from these qualifying groups 'by proportional representation following the rule of the highest average'. ${ }^{43}$ Only after the executive was formed were the ministers required to elect a President and Vice-President and the Executive was charged with conducting decision-making in a 'collegial' fashion. ${ }^{44}$ Like Fiji, New Caledonia experienced considerable litigation on the cabinet entitlements issue, although in New Caledonia legal battles and political controversies also centred on the election of the President and Vice-President, portfolio distribution and the nature of cabinet decision-making.

\section{The 1999 elections}

At the first elections after the introduction of the Noumea Accord in May 1999, the main settler-backed party, the Rassemblement pour la Calédonie dans la République (RPCR), won 24 of the 54 congress seats. The RPCR secured a majority by allying itself with a breakaway Kanak group, the Fédération des Comités de Coordination des Indépendantistes (FCCI, four members). The FCCI had controversially called for a 'mutation' among New Caledonia's political leaders and claimed that the mainstream Kanak coalition, the Front de Libération Nationale Kanak et Socialiste (FLNKS), had 'fulfilled its historic mission' (Chappell 1999b, Radio Australia 7 June 1999). They were heralded by Jacques Lafleur, RPCR leader, as a 'party of peace', but condemned by the larger Kanak-backed parties (Radio Australia 11 May 1999). ${ }^{45}$ The National Front, with four seats, also backed the RPCR-FCCI slate. The RPCR's Jean Lèques became President, while the FCCI's Leopold Jorédie became Vice-President. Of the pro-independence parties, the FLNKS won 12 seats in Congress, while the Parti de Libération Kanak (PALIKA), standing separately, obtained a further six seats. The other mainly settler-backed party, Didier Leroux's Alliance pour la Calédonie, gained three seats, failing to reach the threshold for cabinet representation. 
Table 3: Congress slates and cabinet portfolios after the 1999 polls in New Caledonia

\begin{tabular}{|c|c|c|c|c|}
\hline & \multicolumn{2}{|c|}{ Congress slates } & \multicolumn{2}{|c|}{ Cabinet posts } \\
\hline & No. & $\%$ & No. & $\%$ \\
\hline Qualifying groups: & & & & \\
\hline RPCR (24) - FCCI (4) - FN (4) & 32 & 60.4 & 7 & 63.6 \\
\hline $\begin{array}{c}\text { FLNKS (12) - PALIKA (5) - } \\
\text { LKS }(1)^{1}\end{array}$ & 18 & 34 & 4 & 36.4 \\
\hline Non-qualifying parties: & & & & \\
\hline Alliance pour la Calédonie ${ }^{2}$ & 3 & 5.7 & 0 & 0 \\
\hline Total $^{1}$ & 53 & 100 & 11 & 100 \\
\hline
\end{tabular}

Source: Les Nouvelles-Calédoniennes, May 29, 1999.

Notes: For party abbreviations, see text. LKS = Libération Kanak Socialiste.

${ }^{1}$ Charly Pidjot of FLNKS did not vote, as a result of which the total is 53 rather than 54 .

${ }^{2}$ The Alliance in fact submitted three blank ballots.

In accordance with the new multi-party cabinet rules, Congress decided on an 11-member executive. With 32 of the 54 seats, the RPCR-FCCI obtained seven ministerial portfolios, while FLNKS-PALIKA obtained four positions in cabinet (see Table 3). Initial controversy surrounded the Vice-Presidency, with FLNKS leaders arguing that the position should have gone to the pro-independence groups, rather than to the FCCI. The majority RPCR-FCCI coalition also took the major portfolios, such as economics, labour and education, with the FLNKS receiving health, culture, equipment, and youth and sports. FLNKS leader, Rock Wamytan, protested that the Government was 'drifting away from the spirit and the letter of the Noumea Accord' (Chappell 2000, PINA News online 1 October 1999). In its first year participating in cabinet, the FLNKS repeatedly took cases before the Administrative Tribunal complaining of a lack of 'collegiality' in the conduct of the Executive (Chappell 2000; 2001, Connell 2003). The RPCR leaders insisted on 'majority rule' in executive decision-making, and retained control of all congressional commissions (Chappell 2001, Bastogi 2003, Maclellan 1999, Connell 2003).

On his re-election as Mayor of Noumea in 2001, Jean Lèques resigned the Presidency, an act that automatically led to the fall of his government. A new government was elected by Congress on April 3, 2001. The RPCR's Pierre Frogier was elected President, but now PALIKA's Déwé Gorodé, a Kanak activist and writer, was appointed as Vice-President, thus meeting one of the major FLNKS objections to the Lèques Government. The RPCR again had seven ministers, FLNKS three and Union Calédonienne (UC) one, an allocation that entailed no change in the portfolios allocated to the pro-independence groups (Les Nouvelles-Calédoniennes 4 April 2001). The FCCI challenged the outcome, protesting that it, rather than the FLNKS, was entitled to the 1lth cabinet portfolio. During the executive election of 3 April 2001, the RPCR-FCCI and 
FLNKS had been tied in the contest for the final executive position. The President of Congress employed the rule benefiting the more aged candidate, with the result that the FLNKS' M. Manuohalalo was elected (Oceania Flash 26 September 2001). After a reference by the FCCI, the Council of State reversed the previous decision, applying instead rules that favoured the group which secured the largest number of votes. As a result, the FCCI gained the seat. Wamytan resigned from the Government in protest, but PALIKA's Gorodé remained in cabinet (Oceania Flash 7 November 2001). Although controversies over the implementation of the Noumea Accord and 'collegiality' in cabinet continued, frictions within the FLNKS were becoming increasingly prominent.

Two decisions under the first Frogier Government also confirmed the scope and limitations for the minority in cabinet to exercise an indirect veto over policy, the first of which involved a decision taken under the previous government. On December 21, 2000, then President Lèques had appointed a new Director of the Central Territorial Hospital, publishing the decision in the Official Journal of New Caledonia. The 1999 Organic Law, however, required a countersignature by the Minister of Health, FLNKS' Manuohalalo, who refused on the grounds that proper procedure had not been respected. President Lèques referred the matter to the Administrative Tribunal, which in turn asked for the advice of the Council of State. On July 27, 2001, the Council of State ruled that the minister's refusal rendered the decision invalid, an outcome interpreted by French legal specialist Jean Yves Faberon (2002), as intended to reinforce the Noumea Accord's provisions for 'collegiality' in cabinet.

More importantly, the other article in the 1999 Organic Law that entailed an indirect minority veto provides that if a party participating in the Government collectively resigns, the result is that the entire government falls and needs to be re-elected by Congress. ${ }^{46}$ In October 2002, cabinet offices were moved to a new building. The three FLNKS ministers refused to shift, protesting that the building was designed as an 'annex' to the powerful RCPR-dominated Southern Province headquarters. Describing this as a further example of lack of 'collegiality' in decision-making, UC leader, Gerald Cortot, and all members of the UC list beneath him, collectively resigned from the Executive causing the Government to fall on November 13, 2002 (Oceania Flash 14 November 2002, Chappell 2003). Before the new government was elected, Congress endorsed the RPCR's proposal that the Executive be restricted to 10 members (rather than 11), in the face of UC protests (Oceania Flash 22 November 2002). Outcomes were similar to 1999 and 2001: the RPCR-FCCI won seven, the FLNKS secured two and the UC a single cabinet portfolio. The Administrative Tribunal rejected UC's appeal against the reduction in cabinet size from 11 to 10.47 Frogier was re-elected President on November 28, 2002, with Gorodé again as Vice-President. The pro-independence parties boycotted cabinet meetings in late 2002 (Pacific Islands Report 20 December 2002). 


\section{Outcomes of the 2004 polls}

The 2004 election proved a watershed in New Caledonian politics. It ended an era of government by the RPCR and resulted in multiple political parties securing representation in Congress. It also threatened to produce an impasse. The newly formed Avenir Ensemble and the Rassemblement-UMP (the renamed RPCR ${ }^{48}$ ) were tied on 16 seats each, and the FLNKS and UC counted together also had 16 seats. No party had an absolute majority in Congress and no alliance of parties initially proved able to agree on a new President. One result was that the institutions established under the 1998 Noumea Accords were subjected to a severe test. Eventually, the outcome was consensus, at least between the mainly settler-backed political parties on the election of the newly formed Avenir Ensemble's Marie-Noëlle Thémereau as President. Avenir Ensemble and the pro-independence parties agreed on the re-election to the Vice-Presidency of PALIKA's Gorodé. The new government proclaimed for itself the goal of achieving a more effective style of power sharing than its predecessors.

In the wake of the polls, Congress decided to establish an 11-member executive. Owing to the distribution of Congress seats, the expected entitlement of parties to ministerial portfolios would have given the Rassemblement-UMP and Avenir Ensemble four portfolios each (Les Nouvelles-Calédoniennes 2 June 2004). However, one of the new Rassemblement-UMP Congress members, Suzie Vigouroux, marked the ballot 'Frogier' rather than voting for the Rassemblement-UMP-FCCI list. This rendered her vote invalid and lost the Rassemblement-UMP a crucial vote. Without the Vigouroux vote, the RPCR was entitled to only three cabinet posts. Consequently, Thémereau won the initial election for the Presidency, with Gorodé as Vice-President. Several hours later, however, the resignation of the Rassemblement-UMP, using the same provision as that used in November 2002 by the UC, brought about the fall of the new government (Les Nouvelles Calédoniennes 11 June 2004). As a result of the ensuing legal battles, the Rassemblement-UMP regained the Vigouroux vote. The Administrative Court also advised that the President had to be elected by an absolute majority of six of the 11 cabinet members (rather than a simple majority). ${ }^{49}$ Avenir Ensemble and the Rassemblement-UMP were now tied on four votes each, while UC and Uni-FLNKS again abstained from the presidential election. The possibility of fresh general elections, called by the French High Commissioner, loomed if the impasse was not resolved. Eventually, a compromise was reached. Thémereau received all eight Avenir Ensemble and Rassemblement-UMP votes and was re-elected as President (Bastogi 2004). Gorodé was also re-elected, drawing on the three pro-independence party votes and four Avenir Ensemble votes and two of the votes from the Rassemblement-UMP. 
Table 4: Congress slates and cabinet portfolios in New Caledonia as of June 24, 2004

\begin{tabular}{|c|c|c|c|c|}
\hline & \multicolumn{2}{|c|}{ Congress slates } & \multicolumn{2}{c|}{ Cabinet posts } \\
\hline & No. & $\%$ & No. & \\
\hline Qualifying groups: & & & 4 & 36.4 \\
\cline { 2 - 5 } AE (16) - FN (4) - LKS (1) \\
R-UMP (16) - FCCI (1) & 21 & 38.9 & 4 & 36.4 \\
\cline { 2 - 5 } & 17 & 31.5 & 2 & 18.2 \\
\hline Uni-FLNKS & 9 & 16.7 & 1 & 9.1 \\
\hline UC & 7 & 13 & 11 & 100 \\
\hline \multicolumn{5}{|l|}{} \\
\hline
\end{tabular}

Notes: Elections to the New Caledonian Executive are by secret ballot, and the lists are not released publicly. Nevertheless, references to the size of Congress slates make it possible to calculate combined lists. For abbreviations, see Table 3 and text.

In the new cabinet, portfolios were allocated without the friction witnessed during the presidential election. Gorodé retained the culture portfolio, but also took responsibility for women's affairs and citizenship; UC's Cortot received transport, infrastructure and energy; and PALIKA's Charles Washetine acquired responsibility for teaching and research. Avenir Ensemble's Didier Leroux gained the economy and communications portfolio and the Rassemblement-UMP's Frogier took charge of foreign affairs and trade. President Thémereau described the allocation of ministerial portfolios as being accomplished in 'an entirely collegial fashion, with perfect agreement and without difficulty', while Frogier talked of a 'balanced division' (Les Nouvelles-Calédoniennes 3 July 2004). In some respects, the mainly Kanak-backed parties acquired greater influence in the new government. For example, PALIKA and UC persuaded the Government to strengthen the responsibilities of the Kanak customary Senate, rather than dealing with customary matters through a separate ministerial post. Compromises were also reached with the Rassemblement-UMP, not only on the presidential election issue but with regard to a new meeting of the signatories to the Noumea Accord. Such a meeting had not occurred since June 2003. At first, the Rassemblement-UMP insisted that only those who had signed the accord be represented at the negotiations (i.e., RPCR and FLNKS), pointing out that some Avenir Ensemble leaders (such as Leroux) had voted against the Noumea Accord. Eventually, a compromise was reached by which other parties could be included as part of the RPCR and FLNKS 'historic' delegations.

Verdicts differ on the likely future direction of cooperation under the Noumea Accord, and whether elite conciliation might galvanise Kanak rebellion (Chanter 2006, Crocombe 2001: 424, Chappell 1999b), what emphasis to place on grassroots reconciliation efforts as compared with top-level constitutional arrangements (Maclellan 2005a), or whether the Noumea Accord is merely a delaying tactic designed to ultimately avoid independence (Connell 2003). Although early signs might be promising (Chappell 2005, Maclellan 2005b, Angleviel 2003), the 
potential exists for deadlock if parties representing the different communities fail to cooperate in the Executive. Whichever way, New Caledonia's experiment with a multi-party cabinet proved considerably more successful than that in Fiji. Even if future political directions are uncertain, there is little sign that the design of New Caledonia's laws governing cabinet composition places any significant impediments in the path of cooperation between the pro-independence and settler-backed parties.

\section{Lessons with regards to power-sharing institutions}

Fiji's power-sharing provisions are internationally peculiar. Combining a Westminster-style constitutional framework with a multi-party cabinet proved incongruous; the result was a majoritarian electoral system shorn of the often claimed virtues of such systems coupled with a proportional cabinet formation system without its usual associated merits of fairly and equitably representing the major ethnic communities or other interest groups. Historically, most cabinet power-sharing arrangements have been adopted together with proportional representation systems, as in New Caledonia, Northern Ireland and Switzerland. Proportionality in parliament ensures a reasonably representative election of competing ethnic or interest groups, which are then brought, also proportionally, into government. Majoritarian systems, for better or worse, make likely party seat shares that differ from vote shares. A small favourable nationwide swing in votes results in a big swing in seats to the victorious party. Coalition governments are less likely to be necessary, leaving governing parties free to implement their manifestos undisturbed by compromises with allied parties (hence, the often-heard 'stable government' argument). In the context of a proportionality rule as regards cabinet formation, it will frequently be the case that the Prime Minister's party's majority in Parliament is not dependent on, or even assisted by, parties which the power-sharing provisions bring into cabinet. Conversely, minority parties brought into cabinet are less likely to have their position reinforced by a real strength on the floor of Parliament. Their role in cabinet is more likely under such systems to be solely a function of legal constraints and consequently considerably weaker. Difficulties might arise with power-sharing institutions under either arrangement, but they are much more likely with majoritarian electoral systems.

Specific features in the design of Fiji's power-sharing institutions imparted additional tensions to the process of government formation. Under the 1997 Constitution, governments are potentially formed twice. Initially, the onus is on a potential Prime Minister to persuade the President that he or she can command the support of a majority in the House. ${ }^{50}$ Where a coalition is required, this is likely to be accompanied by inter-party agreements regarding the distribution of ministerial portfolios. Once appointed, the Prime Minister must reform his or her government in accordance with the 10 per cent entitlement 
provision, often incorporating parties from the opposite end of the political spectrum. After the 1999 elections, this posed no great difficulty since i) the FLP held an absolute majority in the House of Representatives, ii) the FLP had a pre-election alliance with the FAP, and iii) the SVT was ruled to have forfeited its entitlement to cabinet participation owing to conditions placed on acceptance. After the 2001 polls, it posed a major difficulty because the coalition forged on the floor of the House (SDL plus CAMV) differed from that required to comply with the multi-party cabinet provisions of the 1997 constitution (SDL plus FLP). In other circumstances, potential Prime Ministers might anticipate the impending constraints of the 10 per cent rule, and form a cabinet accordingly. But a party leader urging claims to the premiership straight after an election is more likely to be able to elicit support from like-minded allies than adversaries. A party from the opposite end of the political spectrum, particularly if it has a substantial representation in Parliament, is more likely to field alternative candidates for the premiership than to anticipate, and acquiesce in the acceptance of, a junior position in a power-sharing cabinet.

The potential alternative arrangement, as used in neighbouring New Caledonia, entails the formation of a multi-party cabinet before the selection of the Prime Minister or President and Vice-President of the Territorial Assembly. As we have seen, first, Congress decides how many ministers will make up the government (somewhere between five and 11: i.e., unlike Fiji, there is a ceiling on membership avoiding over-inflation of cabinet size to accommodate dual coalitions). Second, all groups with more than six seats gain the right to participate proportionally in cabinet, and present lists for inclusion, which can include people not elected to Congress. Groups thus, more reasonably than in Fiji, select their own favoured representatives for cabinet inclusion, rather than leaving this to the discretion of a President/Prime Minister who might belong to a rival political party. New Caledonia's rules are also fairer to smaller parties, since they can combine with bigger parties to enhance the allied group's cabinet entitlement and, in this way, potentially negotiate portfolios of their own. Only after the composition of the Executive has been determined are the President and Vice-President selected, although the President retains freedom to determine the allocation of portfolios among ministers.

The Northern Ireland Good Friday arrangements follow a similar principle, but in these a formula is also used to calculate a proportional distribution of ministries. The First Minister and Deputy are elected by 'parallel consent', i.e., they require Unionist and Nationalist majorities. After this, 'the posts of ministers will be allocated to parties on the basis of the d'Hont system by reference to the number of seats each party has in the assembly'. 51

Oddly, the functioning of Fiji's power-sharing institutions depended ultimately on politicians following Westminster-style conventions regarding cabinet 
government despite the changed context. Years of Westminster government had fostered well-established routines regarding the nature of ministerial responsibilities, and, particularly for ethnic Fijians, acquisition of cabinet or other top-level government positions frequently entailed prestigious status that could be deployed simultaneously to acquire standing in the customary order. For example, after becoming President in December 1987, Ratu Sir Penaia Ganilau was able to use his new position to acquire the Tui Cakau title, covering the province of Cakaudrove and the Tovata confederacy, although this reverted to the descendants of his predecessor after his death. Similarly, the position of Ro Teimumu Kepa as a minister in the Qarase Government enhanced her claim to the powerful Roko Tui Dreketi title after the death of the former titleholder.

Chaudhry's short-lived administration was less convention-bound in this respect, and the affairs of the 1999-2000 government were anyway mostly run through a behind-the-scenes FLP caucus, rather than through cabinet (Field, Baba and Nabobo-Baba 2005). ${ }^{52}$ In this sense, Fiji's multi-party cabinet controversy during 2001-04 was blown out of proportion by the reaction of the SDL Government. Nothing in the 1997 Constitution specified the functions of cabinet, or its numbers or how often it was to meet or even the salaries and perks of ministers. Compliance with the letter of the law was therefore not particularly onerous, and the post-2001 Fijian Government could reasonably straightforwardly have embraced FLP participation in cabinet without making significant concessions in terms of policy. Even if cabinet had continued to play a central role in policy formulation, the Prime Minister was constitutionally free to resolve any internal differences by a vote on the floor of the House.

New Caledonia's arrangements are more flexible than those in Fiji. The Noumea Accord sets out only the principle of a multi-party cabinet; the Government must be 'elected by the Congress on a proportional basis'. How that is done is left up to the Congress. The Administrative Tribunal functions largely in an advisory capacity, although the Council of State's decisions have the force of law. There are mandatory aspects of the New Caledonian institutions, but there is also a recognition that not everything can be set down in law and that, ultimately, the success of the Noumea Accord system rests on voluntary cooperation between former adversaries. Even the most elaborate power-sharing rules are vulnerable to strategic manipulation and do not guarantee cooperation between deeply divided political parties. Where power-sharing institutions have proved effective, cooperation has depended on a prior consensus among political elites, rather than representing an institutionally driven outcome that would have worked effectively irrespective of whether or not elites were oriented towards compromise.

For example, the temporary success of power sharing in South Africa did not owe its origin primarily to ingenious and well-crafted legislation. Rather, F. W. 
De Klerk's National Party and the African National Congress perceived gains to be obtained from sharing power; the former because this implied ministerial responsibilities that it would be unlikely to otherwise secure in the wake of the 1994 polls, the latter because this offered to enhance domestic and international legitimacy, and therefore stability, during the transition from apartheid. As Vincent Maphai (1999: 97) concludes,

Consociationalism was not the cause of tolerance, but the result. Power-sharing was the mechanism adopted to give expression to parties' prior readiness to eschew racially exclusive politics in the interest of mutually beneficial outcomes ... Consociationalism is designed to minimize conflict in 'deeply divided' societies. Yet it would appear that such societies would not adopt consociational measures in the first place until levels of hostility have diminished substantially. 53

In 1990s Northern Ireland, it was the ending of the unionist veto and the recognition that the alternative to power sharing was greater involvement of the southern Irish State in the affairs of the North that exerted pressure on Loyalist parties to sign up to the Good Friday Agreement (McGarry 1998: 854, $858,866,869)$. Both sides henceforth had an interest in making the arrangements operate effectively, even if continuing intransigence stalled the restoration of the Northern Irish Executive. Conversely, in 1970s Northern Ireland and 1960s Cyprus, the dominant groups (Protestants and Greeks respectively) saw little benefit associated with defending power-sharing institutions, whereas minority groups (Catholics and Turks respectively) sought to extend and entrench the legal protections (Palley 1978:17). In both cases, intransigence was encouraged by the links of majorities and minorities with neighbouring powers. Multi-party cabinet rules might serve to set in place meaningful parameters, which with time become accepted principles encouraging cooperation (as in Switzerland), but the bare legal bones of mandatory arrangements are unlikely, in themselves, to transcend top-level political conflict or to bring antagonistic elites into cooperative arrangements.

There were numerous reasons for the greater success of power sharing in New Caledonia than in Fiji. Fiji's divisions were in many ways sharper, and the incentives for accommodation by the indigenous elite were less than those confronting the RPCR leadership. Violent resistance by Kanaks in the 1980s destabilised the French Pacific territory, and political realignments threatened to fracture the precarious unity of the settler parties, which, after all, had emerged only in the late 1970s as Kanak opinion hardened around the independence issue. ${ }^{54}$ Time also played its part in building consensus around the new compact, which took a decade to move from the Matignon to the Noumea Accord. Whereas in 1988 the majority of voters in the predominantly non-Kanak south of the Grande Terre had opposed the Matignon Accord, in the Noumea Accord 
referendum a decade later 63 per cent of those in the Southern Province voted 'yes' (Chappell 1989:154; 1999b:434-5). Fiji's 1997 Constitution was much more of an elite deal struck between the leaders of political parties; one which came unstuck in large part because its key architects were subsequently defeated at the polls (indicating their failure to win popular support for the new alliance by demonstrating policy advantages of cooperation). Nevertheless, Fiji's Constitution survived, due to its restoration by the law courts in March 2001. What did not survive unaltered, again because of the decision (and Westminster-based proclivities) of the court, were the multi-party power-sharing provisions, which were so diluted as to permit a reversion to majoritarian cabinet formation. In this paper, my argument has been that one part of the reason for the failure of power sharing in Fiji had to do with institutional design, even if other factors also made cooperation in multi-party cabinets much more difficult to achieve in Fiji than in New Caledonia.

\section{References}

Akinyele, R. T. 2000, 'Power-sharing and Conflict Management in Africa: Nigeria, Sudan and Rwanda', Africa Development, XXV, 3-4: pp. 209-33.

Angleviel, F. 2003, “The Bet on Intelligence": Politics in New Caledonia, 1998-2002', State, Society and Governance in Melanesia Discussion Paper, 2003/4. Canberra, The Australian National University.

Barry, B. 1975a, 'Political Accommodation and Consociational Democracy', British Journal of Political Science, 5: pp. 477-505.

Barry, B. 1975b, 'The Consociational Model and its Dangers', European Journal of Political Research, 3: 393-412.

Bastogi, M. 2004, 'Le Gouvernement de la Nouvelle-Calédonie Issu des Elections du 9 Mai 2004', Revue Juridique Politique et Économique de Nouvelle Calédonie, 4, 2: pp. 14-19.

Bastogi, M. 2003, 'Le Gouvernement de la Nouvelle-Calédonie à l'épreuve de la durée', Revue Juridique Politique et Économique de Nouvelle Calédonie, 1, 1: pp. 30-6

Cama, N. 2005, 'Stop, Take Stock, Move On', Daily Post, 5 March.

Chanter, A. 2006, 'Party Fragmentation and the New Political Logic in New Caledonia', in R. Rich et al., Political Parties in the Pacific, Pandanus Books: p. 21

Chappell, D. 2005, 'New Caledonia', The Contemporary Pacific, 17, 2: pp. 435-48;

Chappell, D. 2003, 'New Caledonia', The Contemporary Pacific, 15, 2: p. 452.

Chappell, D. 2001, 'New Caledonia', The Contemporary Pacific, 13, 2: p. 542

Chappell, D. 2000, 'New Caledonia', The Contemporary Pacific, 12, 2: p. 515-520. 
Chappell, D. 1999a, 'The Noumea Accord; Decolonization without Independence in New Caledonia', Pacific Affairs, 72, 3: pp. 373-391.

Chappell, D. 1999b, 'New Caledonia', The Contemporary Pacific, 11, 2: p. 416.

Chappell, D. 1989, 'New Caledonia', The Contemporary Pacific, 2, 2: p. 154.

Connell, J. 2003, 'New Caledonia: An Infinite Pause in Decolonisation?' The Round Table, 368: pp. 127-8.

Connell, J. 1987, New Caledonia or Kanaky? The Political History of a French Colony, National Centre for Development Studies, Canberra: The Australian National University.

Crocombe, R. 2001, The South Pacific, Suva: University of the South Pacific. de Fontenay, P. 2001, 'New Caledonia: Problems and Promises - A Survey', Pacific Economic Bulletin 16, 2: pp. 15-26.

Dornay, M. 1984, Politics in New Caledonia, Sydney University Press.

Faberon, J. V. 2002, 'Nouvelle-Calédonie: Les Difficultés d'un Gouvernement Constitué à la Représentation Proportionelle', Actualité Juridique, Droit Administratif 58, 2: pp. $113-117$.

Field, M., Baba, T. and U. Nabobo-Baba, 2005, Speight of Violence: Inside Fiji's 2000 Coup, Canberra: Pandanus Books;

Fraenkel, J. 2003. 'Electoral Engineering and the Politicisation of Ethnic Frictions in Fiji', in S. Bastian, S. and R. Luckham (eds), Can Democracy be Designed? The Politics of Institutional Choice in Conflict-Torn Societies, IDS, Sussex: Zed Books Ltd: pp. 220-52.

Fraenkel, J. 2001, 'The Alternative Vote System in Fiji: Electoral Engineering or Ballot-Rigging?' Journal of Commonwealth and Comparative Politics, 39, 2: pp. 1-31.

Fraenkel, J. 2000, 'The Clash of Dynasties and the Rise of Demagogues: Fiji's Tauri Vakaukauwa of May 2000', Journal of Pacific History 35: pp. 295-308.

Hudson, M. 1997, 'Trying Again: Power-Sharing in Post-Civil War Lebanon', International Negotiation, 2: pp. 103-22.

Kettley, C., J. Sullivan and J. Fyfe, 2001. 'Resolving Self-Determination Disputes Through Complex Power-Sharing Arrangements', Workshop February 9-10, 2001, Pembroke College, University of Cambridge, University of Cambridge and Carnegie Corporation of New York, p. 14n. Retrieved 10 October 2006 from http://www.intstudies.cam.ac.uk/centre/cps/

Kliot, N. 1987, 'The Collapse of the Lebanese State', Middle Eastern Studies 23: pp. 54-74. 
Koelble, T. and A. Reynolds, 1996, 'Power-sharing Democracy in the New South Africa', Politics and Society, 24, 3: pp. 221-36.

Lal, B. 1992. Broken Waves: A History of the Fiji Islands in the Twentieth Century, University of Hawai'i Press:

Lijphart, A. 2004, 'Constitutional Design for Divided Societies', Journal of Democracy, 15, 2: pp. 96-109.

Lijphart, A. 2002, 'The Wave of Power-Sharing Democracy', in A. Reynolds (ed.), The Architecture of Democracy: Constitutional Design, Conflict Management, and Democracy, Oxford and New York: Oxford University Press.

Lijphart, A. 1991a, 'The Power Sharing Approach', in J. Montville (ed.), Conflict and Peacemaking in Multiethnic Societies Lexington, Massachusetts: Lexington Press;

Lijphart, A. 1991b, 'Constitutional Choices for New Democracies', Journal of Democracy 15: pp. 2.

Lijphart, A. 1998, 'South African Democracy: Majoritarian or Consociational?', Democratization 5: pp. 4

Maclellan, N. 2005a, 'Conflict and Reconciliation in New Caledonia: Building the Mwâ Kâ', State, Society and Governance in Melanesia Discussion Paper, 2005/1. Canberra, The Australian National University.

Maclellan, N. 2005b, 'From Eloi to Europe: Interactions with the Ballot Box in New Caledonia', Commonwealth \& Comparative Politics, 43, 3: pp. 394-417.

Maclellan, N. 1999, 'The Noumea Accord and Decolonisation in New Caledonia', Journal of Pacific History, 34, 3: pp. 245-52

Maphai, V. T 1999, 'The New South Africa: A Season for Power-sharing', in L. Diamond and Marc F. Plattner (eds), Democratization in Africa, Baltimore: John Hopkins Press.

McGarry, J. 1998, 'Political Settlements in Northern Ireland and South Africa', Political Studies XLVI: pp. 853-70.

Nasrallah, F. 1999, 'Lebanon: The Two Republics', in D. Maclver, 1998, (ed.), The Politics of Multinational States, Basingstoke: Macmillan.

Norton, R. 2004, 'Seldom a Transition with such Aplomb: From Confrontation to Conciliation on Fiji's Path to Independence', Journal of Pacific History, 39, 2: pp. 163-84.

Norton, R. 2002. 'Accommodating Indigenous Privilege; Britain's Dilemma in Decolonising Fiji', Journal of Pacific History, 37, 2: pp. 133-56 
O'Leary, B. 1999, 'The Nature of the British-Irish Agreement', New Left Review 233: pp. 66-96.

O'Leary, B., B. Grofman and J. Elklit, 2005, 'Divisor Methods for Sequential Portfolio Allocation in Multi-Party Executive Bodies: Evidence from Northern Ireland and Denmark', American Journal of Political Science, 49, 1: pp. 198-211.

Palley, C. 1978, Constitutional Law and Minorities, London: Minority Rights Group.

Parliament of Fiji 1997, 'Report of the Joint Parliamentary Select Committee on the Report of the Fiji Constitutional Review Commission', Parliamentary PaperNo 17. of 1997, S. G1

Reynolds, A. 1999, Electoral Systems and Democratization in Southern Africa, Oxford University Press.

Reynolds, A. 1995, 'Constitutional Engineering in Southern Africa', Journal of Democracy 6, 1: pp. 90.

Seaver, B. M. 2000, 'Regional sources of Power-Sharing Failure: The Case of Lebanon', Political Science Quarterly 115: pp. 247-71.

Spears, I. S. 2002, 'Africa: The Limits of Power-Sharing', Journal of Democracy 13, 3: pp. 123-36.

Spears, I. S. 2000, 'Understanding Inclusive Peace Agreements in Africa: The Problems of Sharing Power', Third World Quarterly, 21, 1: pp. 105-18.

\section{ENDNOTES}

1 I am indebted to Marion Bastogi, of the University of New Caledonia, for assistance in assembling materials on cabinet formation in New Caledonia.

2 Good Friday Agreement, http://www.nio.gov.uk/agreement.pdf

3 Constitution of the Republic of South Africa, c. 200 of 1993, s. 88(1)-(3), as amended by Act 14 of 1994,

s. 2. For the rules governing Deputy Presidents, see Constitution of the Republic of South Africa, Act 200 of 1993, s. 84(1).

4 The National Party had 20.4 per cent of the vote, and the IFF 10.5 per cent.

5 Each voter had two votes; one in his or her own communal constituency and another in one of the open constituencies.

6 The Carnegie Project on 'Complex Power-Sharing and Self-Determination' excludes New Caledonia on the questionable grounds that 'the settlement established by the 1998 Noumea Accords does not in essence qualify as a complex power-sharing arrangement. The Noumea Accords instead provide for the gradual devolution of powers from Paris to New Caledonia over 15 years, and grants the territory's Congress loi du pays, or local autonomy. The case of New Caledonia is therefore exempt from this study on several grounds: there is a lack of international involvement, the arrangement is essentially one of autonomy, and in the longer term it appears that the dispute will be settled wholly in favour of the Kanaks' (see Kettley and Fyfe 2001). In fact, there is considerable international involvement, not only from metropolitan France, but by virtue of the inclusion of New Caledonia on the UN Decolonisation list, and it is far from universally accepted, at least among the French loyalists, that the Noumea Accord will result in eventual independence. The project also includes Bougainville, where the peace agreement was influenced by the one in New Caledonia and similarly puts off the independence issue for a later referendum. 
7 The only exception, Poseci Bune, abandoned his Fijian communal seat, joined the Fiji Labour Party and stood successfully in the 70 per cent Indo-Fijian Labasa open constituency.

8 South Africa was a poor model for Fiji. The issues were entirely different. Power sharing in Fiji was not merely a potential transitional arrangement, as it was in South Africa.

9 On the strengths and weaknesses of the new voting system (not covered in this paper), see Fraenkel $(2003 ; 2001)$.

10 Supreme Court of Fiji, Miscellaneous Case No. 1 of 1999 between the President of the Republic of the Fiji Islands and 1. Inoke Kubuabola (leader of the Opposition), 2. Mahendra Pal Chaudhry, Prime Minister, Government of the Fiji Islands and Leader of the Fiji Labour Party and 3. Adi Kuini Speed, Leader of the Fijian Association Party (cited as The President of the Republic of the Fiji islands v. Kubuabola \& ors, Misc. 1/1999, September 3, 1999).

${ }^{11}$ Leader of the Opposition, Inoke Kubuabola, initially claimed the right to nominate all eight opposition senators, but the FLP and the FAP claimed entitlement to nominate candidates for inclusion among the opposition senators (according to the provisions of s. 64[2] cited above). The court resolved the dispute by rejecting the claim that the Prime Minister's party was entitled to nominate opposition senators, yet it allowed the FAP, despite being in the governing coalition, to share in the nominees of the Leader of the Opposition.

12 See 'Statement of Agreed Facts and Issues', appended to 1999 Supreme Court Judgment.

13 The author of the SVT letter, Jone Dakuvula, the party's then Election Campaign Consultant, later became a prominent civil society activist urging power sharing in Fiji. He was to regret these conditions placed on cabinet entry, and to regard this episode as a major failure to secure a viable multi-ethnic government in Fiji. The conditions were recommended by MPs Jim Ah Koy and Sam Speight, who had themselves declined to be selected for cabinet positions. There was no objection from the other SVT MPs (Jone Dakuvula, personal communications, July 2004, November 2005).

14 The figure chosen, two or three, depends on which interpretation of Section 99(5) is chosen, as will later become apparent.

15 Supreme Court of Fiji, Miscellaneous Case No. 1 of 1999, Original Jurisdiction, p. 22.

16 This was raised to 28 seats after the Court of Disputed returns overturned the result for Nadi Open, resulting in a recount. As a result, the solitary NFP MP lost his seat to a Labour MP.

17 Qarase to Chaudhry, September 10, 2001.

18 'Korolevu Declaration', Parliamentary Paper 15/99, S. 2. (b) - emphasis added.

19 'Korolevu Declaration', (2) (b); (4) (a).

20 Qarase to Chaudhry, September 12, 2001.

21 For an indication of the importance of such balanced provincial allocations in indigenous Fijian politics, see Cama (2005).

22 Court of Appeal, Chaudhry v. Qarase, President \& Attorney-General, Civil Action No. 282 of 2001, Misc 1/2001, February 15, 2002: p. 14.

23 High Court of Fiji at Lautoka, April 24, 2002.

24 Qarase, President \& Attorney-General v. Chaudhry, Civil Appeal No. CBV 0004 of 2002S, Judgment, July 18, 2003, S117.

25 Qarase et al. v. Chaudhry, 2003,S111.

26 Qarase et al. v. Chaudhry, 2003, S142 - emphasis added.

27 No mention of these cases was made in any of the Court of Appeal or Supreme Court judgments.

28 As we saw above, the FLP's membership of the House had risen from 27 to 28 seats after a recount gave them the Nadi Open seat.

292003 Supreme Court judgment S21; 2002 Court of Appeal judgment, p. 16.

30 Qarase to Chaudhry, August 11, 2003, cited in Daily Post, August 18, 2003, full letter reproduced in Sunday Post, July 27, 2003; see also 'Prime Minister, Laisenia Qarase's Statement on the Inclusion of the Fiji Labour Party in a Multi-Party Cabinet', in Fiji's Business Magazine, September 2003.

31 The number of SDL ministers in cabinet had risen from 20 straight after the election to 22 by the time of the 2003 Supreme Court case.

32 That this was having some impact was suggested by the liquidation of the Party of National Unity (PANU), the last-surviving Fijian party that had been allied to the FLP as part of the People's Coalition (although this party was later re-registered in the run-up to the 2006 polls). Tomasi Vakatora, the indi- 
genous Fijian member of the CRC, publicly denounced the multi-party cabinet provisions in the Constitution on numerous occasions, pointing out that these had not been part of the Reeves Report.

33 See Josaia Dani, SDL General Secretary, letter, Daily Post 3 August 2003.

34 Opinion of the Supreme Court in the Matter of Section 123 of the Constitution Amendment Act 1997 and in the Matter of a Reference by the President for an Opinion in Questions as to the effect of Section 99 of the Constitution, Miscellaneous Case No. 1 of 2003, Judgment, July 9, 2004 (hereafter 2004 Supreme Court judgment), Section 24.

35 The three sections of the 1997 Constitution (1997 Constitution, 99[6], [7] and [8]) strongly imply that the Prime Minister's party is also to receive proportional entitlements to cabinet portfolios.

36 Reference was made to the March 15, 2002, Supreme Court judgment on the issue of Senate appointments, which had expressly interpreted the earlier 1999 judgment as entailing a calculation, in the case of two parties, 'in accordance with the proportion the size of their respective memberships in the house bore to one another' (i.e., rather than to the total membership of the House), Supreme Court of Fiji, 'In the Matter of section 123 of the Constitutional Amendment Act 1997', Opinion of the Supreme Court, March 15, 2002: p. 10.

372004 Supreme Court judgment, s97, p. 37.

38 Ibid., S114.

39 Ibid., S117, p. 42.

40 'Opinion of Gault JSC', appended to 2004 Supreme Court judgment, S17, p. 5.

41 For further details regarding the Noumea Accord, see Maclellan (1999; 2005)

42 Loi Organique Modifiée No. 99-209 du 19 Mars 1999 Relative à la Nouvelle Calédonie (henceforth 1999 Loi Organique); Deliberation No. 009 Modifiée du 13 Juillet 1999 Portant Reglement Interieur du Congress de la Nouvelle-Calédonie (henceforth 1999 Interior Rules).

431999 Loi Organique, Art. 79, 109, Art. 110; 1999 Interior Rules, Art. 11.

44 'New Caledonia's Executive will become a collegial Government, elected by and answerable to Congress' (Noumea Accord, S. 2.3, see also 1999 Loi Organique, Art. 128).

45 The FCCI lost three of its four Congress seats at the next election in 2004, and some senior members were convicted on corruption charges.

461999 Loi Organique, Art. 121.

47 Tribunal Administratif de Nouvelle-Calédonie, No. 02-0792, Séance du Novembre 26, 2002; Lecture du Novembre 27, 2002.

48 Before the 2004 elections, theRPCR changed its name to Rassemblement-UMP, in line with new centre-right alliances in mainland France, which brought together the Rassemblement pour la République (RPR), Union pour la Démocratie Française (UDF) and Liberal Democrats, under the banner of the Union pour un Mouvement Populaire (UMP).

49 Tribunal Administratif de la Nouvelle-Calédonie, Avis No. 0504 du Juin 22, 2004.

50 The President offers the premiership to the 'member of the House of Representatives who, in the President's opinion, can form a government that has the confidence of the house' (1997 Constitution s. 98).

51 Good Friday Agreement [15], [16], 5. (d), (i); see also (O'Leary, Grofman and Elklit 2005)

52 Ema Tagicakibau, FAP, personal communication, August 2005.

53 see also the discussion in Reynolds (1999: 118-20)

54 For accounts of the schisms among the settler parties in the pre-1970s era, see Dornay (1984) and Connell (1987). 